Article

\title{
Development of an Eco-Sustainable Solution for the Second Life of Decommissioned Oil and Gas Platforms: The Mineral Accretion Technology
}

Lucia Margheritini ${ }^{1,2,3}$, Giuseppina Colaleo ${ }^{1}$, Pasquale Contestabile ${ }^{1,4}$, Trine Larsen Bjørgård ${ }^{2}$, Morten Enggrob Simonsen ${ }^{2}$, Caterina Lanfredi ${ }^{1}$, Antonio Dell'Anno ${ }^{5}$ and

Diego Vicinanza ${ }^{1,6, *(1)}$

1 Department of Engineering, University of Campania, via Roma 29, 81031 Aversa, Caserta, Italy; lm@civil.aau.dk (L.M.); giuseppina.colaleo@unicampania.it (G.C.); pasquale.contestabile@unicampania.it (P.C.); caterina.lanfredi@unicampania.it (C.L.)

2 Department of Civil Engineering, Division of Water and Environment, Aalborg University, Thomas Manns Vej 23, 9220 Aalborg Ø, Denmark; tlb@bio.aau.dk (T.L.B.); mes@bio.aau.dk (M.E.S.)

3 Department of Chemistry and Bioscience, Aalborg University, Niels Bohrs Vej 8, 6700 Esbjerg, Denmark

4 Inter-University National Consortium for Marine Sciences (CoNISMa), P.zzale Flaminio, 00144 Rome, Italy

5 Department of Life and Environmental Sciences, Polytechnic University of Marche, Via Brecce Bianche, 60131 Ancona, Italy; a.dellanno@univpm.it

6 Stazione Zoologica Anton Dohrn, Villa Comunale, 80121 Napoli, Italy

* Correspondence: diego.vicinanza@unicampania.it; Tel.: +39-081-5010245

Received: 5 February 2020; Accepted: 28 April 2020; Published: 5 May 2020

\begin{abstract}
With the approaching end of the productive lives of offshore oil and gas platforms, the issue about decommissioning and what to do with existing structures arises. In this regard, this study aims to test solutions, at a preliminary level, for the eco-sustainable reuse of platforms at the end of their extraction phase. In particular, mineral accretion technology is applied by low-voltage electrolysis of seawater due to the precipitation of calcium carbonate on a cathode material in order to assess the protection capacity of the platforms against corrosion. This approach allows the extension of a platform's "life" under a more sustainable purpose. The results, derived from laboratory and field experiments, will allow us to reduce uncertainties and define the best operating conditions to increase the efficiency of the mineral accretion technology in the marine ecosystem. The data collection on the main parameters that influence the process (i.e., temperature, salinity, and applied current) and the quantitative analysis of the collected material allowed us to acquire a better knowledge about mineral composition and deposition rate.
\end{abstract}

Keywords: decommissioning, oil and gas platforms; mineral accretion technology; calcareous deposits

\section{Introduction}

The growing concern about the effect of climate change is leading the energy sector in moving from fossil fuel to renewable energies. The transition may consist in the replacement of production facilities, or in their conversion or repowering, maximizing the efficiency and minimizing the environmental impact. An important form of energy transition can be represented by the reuse of offshore oil and gas $(O \& G)$ platforms at the end-of-life production phase [1].

Offshore oil and gas platforms have a limited duration of operations (average productive phase from 10 to 50 years). In the world, there are currently more than 7500 structures in offshore waters, located on the continental shelves of about 53 different countries (about 4000 are located in the Gulf of Mexico, around 950 in Asia, around 700 in the Middle East, and 600 in Europe, the North, and north-east 
Atlantic) [2,3]. About $0.4 \%$ of the world's oil and gas reserves are located in the Mediterranean basin with 127 offshore platforms. These offshore structures are mainly located in the central Mediterranean sea, in the northern and central Adriatic Sea at depths from ca. 10 to $120 \mathrm{~m}$, and also in the Ionian Sea and the Sicily channel [4].

About $85 \%$ of O\&G platforms will become obsolete and will require removal within the next ten years [5]. Accordingly, this is raising the issue about how to manage the existing platforms' decommissioning or reconversion. Possible solutions have been investigated for both fixed offshore platforms and subsea offshore pipelines (Martins et al., 2019). Figure 1 shows the possible options available for the decommissioning of O\&G platforms, distinguishing between fixed offshore platforms and subsea offshore pipelines.

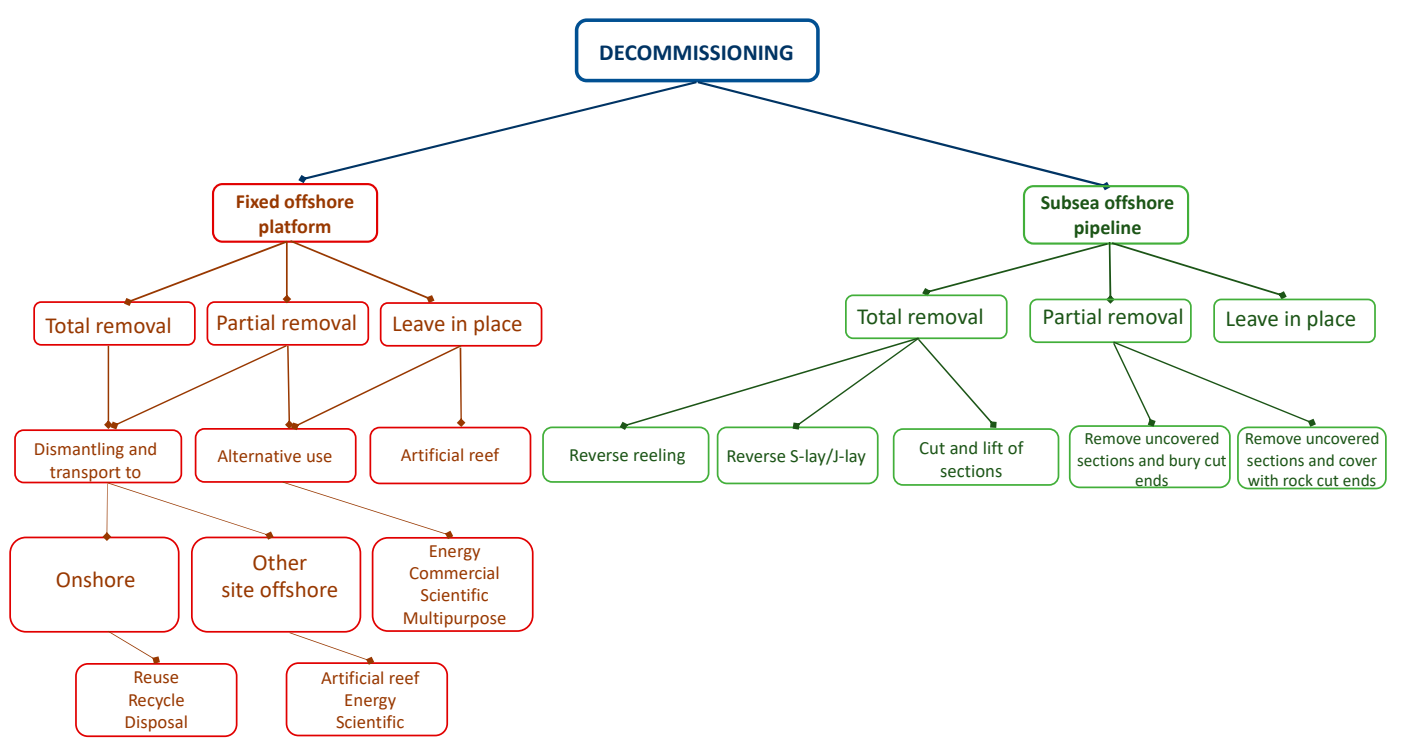

Figure 1. Decommissioning options of offshore assets according to Martins et al., 2019 [6].

Most nations require the complete removal of obsolete structures; however, this practice presents significant socio-economic and ecological challenges $[7,8]$.

The complete removal policies are based on the assumption of "leaving the seabed as found" and apparently could represent the most ecologically sustainable option. However, it is known that, during their productive lives, the platforms are able to support numerous and diversified fish and invertebrate assemblages, also of commercial interest [9], many of which are of great ecological importance and/or protected by different international and national legislations. These favorable conditions are reinforced by the enforcement of exclusion zones around oil platforms that prevent the exploitation of living biological resources. It is therefore unlikely that the removal of these structures represents the best practice from an environmental/ecological point of view, and this awareness has led some nations to leave obsolete structures to act as artificial reefs and/or to find alternative solutions for their sustainable reuse [9].

The international legal framework on decommissioning has been established over the past fifty years. Currently, the activities are regulated by three international conventions and by a series of guidelines, the applicability of which depends on the area in which the infrastructures are located.

The main objective of the conventions is to ensure the safety of navigation and the protection of the marine environment during the decommissioning operations. The international reference conventions are summarized below:

- Geneva Convention [10] (1958-United Nations Geneva Convention on the Continental Shelf) is the first document relating to the removal of offshore installations. In particular, the Art. 5 of this convention states that "all abandoned or unused installations must be removed." 
However, the Convention does not identify the parts of the infrastructure to be removed; it follows that, at least for the conduct, the Convention does not establish a strict obligation to remove.

- United Nations Convention on the Law of the Sea (UNCLOS) [11], which aims to protect and preserve the marine environment as well as conserve and manage living marine resources. The article specifies that: "Every installation or structure that has been abandoned or disused must be removed to guarantee the safety of navigation, taking into account all the generally accepted international standards issued by the competent international organization in this regard. It is carried out with due regard to fishing, the protection of the marine environment, the rights and duties of other States. Adequate information must be provided in relation to the depth, positioning, and size of installations or structures not completely removed."

- IMO Conventions (International Maritime Organization) [12], whose main objective is the promotion of cooperation between countries on navigation issues.

- London Convention on the Prevention of Pollution of the Seas Following Discharges [13] (1972): Explicitly regards the sale of offshore platforms at sea, even if only partially, contemplating a general ban on the discharge of any "waste or other materials in any form or condition except as otherwise specified"; it lists the specific substances and types of waste and the management methods;

- Oslo (1972) and Paris (1992) Conventions (OSPAR: Convention for the Prevention of Marine Pollution by Dumping from Ships and Aircraft, signed in Oslo on 15 February 1972, succeeded by the Convention for the Protection of the Marine Environment of the North-East Atlantic, signed in Paris on 9 September 1992) [14], which adopted a document in 1998 related to the disposal of disused installations and how to implement the necessary measures to protect the north-east Atlantic against the adverse effects of human activities;

Moreover, the following are worthy of noting: The Barcelona Convention for the Protection of the Mediterranean Sea against Pollution (1976) [15], the Basel Convention on the Control of Transboundary Movements of Hazardous Wastes and their Disposal (1989) [16], and the Helsinki Convention on the Protection of the Marine Environment in the Baltic Area (1992) [17].

Recently, there has been an increase in the number of research projects about the assessment of obsolete $O \& G$ platforms as a potential source of multi-use hubs for wind and wave energy, as well as other environmental issues (e.g., MAREenergy [18], MERMAID [19], SDWED [20], THESEUS [21], MUSES [22]). The high demand from the fishery sector and the more and more stringent environmental constraints are driving aquaculture development and blue energy farms to go further offshore [23,24].

In Italy, recently, the Ministerial Decree dated 15 February 2019 [25] defined the "National Guidelines for the disposal of mining platforms for the cultivation of hydrocarbons at sea and related infrastructures."

The Decree promoted innovative principles such as the reuse of existing platforms. In particular, the concept of "reuse project" was introduced, which considers the analysis of the production potential in relation to fish farming, agriculture, and offshore renewable energy. Thus, the Italian Guidelines represent a first concrete step towards the achievement of one of the sustainable energy policy objectives in the upstream sector through the identification of the best technologies available for mining disposal, and focusing on evaluating any innovative alternative uses with a view to the circular economy and "blue growth".

In this context, the PLaCE [26] project aims at investigating for the first time at the national level cutting-edge technologies and solutions for the eco-sustainable reuse of offshore platforms close to end of their productive phase and located in the Adriatic Sea in the offshore waters of the Abruzzo region. The cutting-edge activities of the project will include the application of innovative eco-sustainable strategies of aquaculture based on integrated shellfish and holothurian farming, design and development of innovative systems for renewable energy generation needed for multipurpose platform activities, the development of innovative integrated systems for the assessment of ecological sustainability of multipurpose platform activities and their maintenance, cost-benefit 
analyses, and business scenarios that also take recreational aspects into account. All of the activities revolve around a refurbished decommissioned O\&G platform, to be electrified in a way similar to Impressed Current Cathodic Protection methods, but with different voltages and current intensities. In particular, the project will test a life-extension strategy for reutilization of offshore platforms into a new and eco-sustainable economy, based on mineral accretion technology under low-voltage electrolysis of seawater. The technology offers both protection against corrosion and precipitation of a thick layer of calcium carbonate over the structure. The high compatibility of the accretion (mineral deposition) with the marine environment promotes rapid ecosystem enhancement. This technology is already used for coral reef restoration $[27,28]$ in areas presenting favorable water temperature conditions (i.e., high temperatures) and promotes higher yield or deposition rates.

It is now clear, however, that the implications of the eco-sustainable reuse of offshore platforms can be feasible only if an extension of the original anticipated operational lifetime of the asset can be guaranteed. In fact, for aging facilities, an increasing number of defects due to degradation has to be expected [29]. O\&G platforms are exposed to conditions of stress that will ultimately degrade the material from its initial state. Therefore, it is imperative to boost the interest of researchers and engineers to develop economic and environmentally friendly solutions for life extension of offshore platforms.

In this vein, the present work, carried out within the PLaCE project, aims to improve the knowledge on mineral accretion technology in order to protect the structures from corrosion, allowing the potential extension of lifetime with the changed purpose of the structures, and generating a substrate/matrix of calcium carbonate that is highly colonizable by marine organisms. The steel/calcium carbonate structure integrates the carbonate matrix's high compressive strength with the metal's tensile strength, thus creating a material with greater rigidity and stability than the steel alone.

The results presented here derived from experiments carried out both in the field (on a site in the North Sea) and in the laboratory. The experiments will constitute the base of knowledge about mineral deposition technology in conditions of waters cooler than tropical/subtropical waters, allowing the reduction of uncertainties and the definition of the most suitable operating conditions for the application of mineral accretion technology in marine systems with water temperatures below $21^{\circ} \mathrm{C}$.

\section{Mineral Accretion Technology}

The mineral accretion technology uses seawater electrolysis to precipitate calcium carbonate on a cathode. This technology was designed in its original form by Wolf [30] as an innovative process for the production of sustainable material at a low cost and to replace or implement cementitious applications. In recent years, this technology has been used mainly in tropical areas to restore and stabilize shorelines, control erosion of shorelines, and create artificial reefs $[27,28,31]$. Figure 2 shows an example of a mineral electrodeposition used for the creation of an artificial coral reef in subtropical waters.

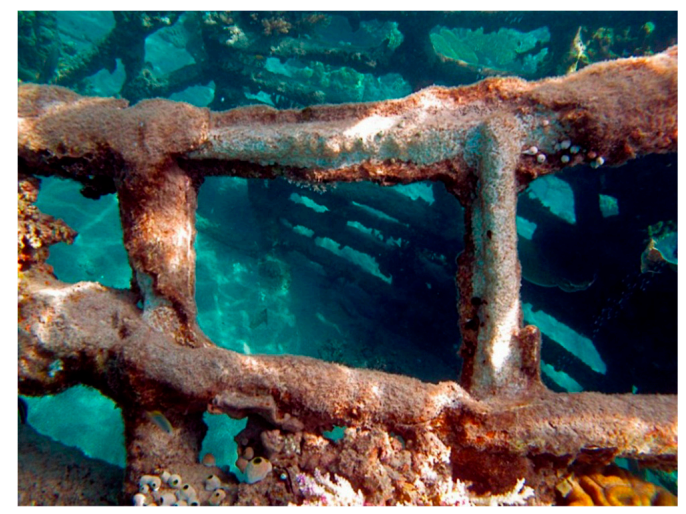

Figure 2. Example of mineral electrodeposition [32]. 
Deposition of $\mathrm{CaCO}_{3}$ is common in the field of cathodic protection (CP) of steel and has therefore been widely investigated [33]. In seawater, during the application of cathodic protection, a scale layer forms on the metal surface. As a function of its chemical composition and compactness, it can improve the metal's protection against corrosion by reducing the oxygen diffusion $[34,35]$.

Material is accumulated by applying a low-voltage electric current to submerged conductive materials, a process known as electrolysis, which causes the precipitation of some dissolved elements (i.e., $\mathrm{Mg}^{2+}, \mathrm{Ca}^{2+}$ ) present in the seawater (Table 1) on the cathode [36].

Table 1. Major elements present in seawater at 3.5\% salinity.

\begin{tabular}{ccc}
\hline Ion & Concentration, $\mathbf{g} / \mathbf{k g}$ & Percent Free Ion, $\%$ \\
\hline $\mathrm{Cl}^{-}$ & 19.353 & 100 \\
\hline $\mathrm{Na}^{+}$ & 10.784 & 98 \\
\hline $\mathrm{Mg}^{2+}$ & 1.284 & 89 \\
\hline $\mathrm{SO}_{4}{ }^{2-}$ & 2.712 & 38 \\
\hline $\mathrm{Ca}^{2+}$ & 0.412 & 89 \\
\hline $\mathrm{K}^{-}$ & 0.399 & 98 \\
\hline $\mathrm{HCO}_{3}{ }^{-}$ & $0.107 *$ & 79 \\
\hline
\end{tabular}

In more detail, electrolysis is a method separating bonded elements and compounds by passing an electric current through the elements. As the electricity from the power supply passes through the water between electrodes (cathode, negatively charged, and anode, positively charged), the water will be able to split into its compounds: Positively charged hydrogen and negatively charged hydroxide ions [37].

$$
2 \mathrm{H}_{2} \mathrm{O} \rightarrow 2 \mathrm{H}_{2}+\mathrm{O}_{2}
$$

Seawater can be electrolyzed because it contains positively charged sodium ions $(\mathrm{Na}+)$ and negatively charged chloride ions $\left(\mathrm{Cl}^{-}\right)$. This specific liquid contains ionic compounds and can conduct electricity when they dissolve in water. This is called an electrolyte.

Electrolysis in saltwater will split into hydrogen $(\mathrm{H}+)$ and chlorine $(\mathrm{Cl})$ gas; the chlorine is reached by a secondary reaction.

$$
\begin{aligned}
& \text { Cathode: } 2 \mathrm{H}^{+}(\mathrm{aq})+2 \mathrm{e}^{-} \rightarrow \mathrm{H}_{2}(\mathrm{~g}) \\
& \text { Anode: } 2 \mathrm{Cl}^{-}(\mathrm{aq}) \rightarrow \mathrm{Cl}_{2}(\mathrm{~g})+2 \mathrm{e}^{-}
\end{aligned}
$$

Two electrodes are used, one negatively charged (i.e., the cathode), and the other positively charged (the anode). Positively charged ions (cations) attract the negatively charged ions (anions) and vice versa. This means that the positively charged ions will move towards the cathode and the negatively charged ions will move towards the anode.

Metals have different electrode potentials. The anodes used for electrolysis are sacrificial anodes, which means that they sacrifice themselves, keeping the cathode from corroding. Sacrificial anodes are created from metal with a more negative electrochemical potential than the cathode. The anode metal dissolves into the electrolyte, and deposit collects on the cathodic metal. The electrolyte and the impressed potential provide an ion-crossing movement, which means that ions move from the anode to the cathode. This reaction results in a faster corrosion of the anode than it otherwise would, and the corrosion at the cathode is inhibited. This means that a specific anode material, such as titanium, should be used for the mineral deposition.

When at least $1.23 \mathrm{~V}$ of power is supplied to the structure, electrolysis is initiated. Experiments that were conducted before [27,37] in the world have used different voltages and currents, as well as different structures for the cathodes. 
Water is broken down into $\mathrm{H}^{+}$and $\mathrm{OH}^{-}$ions, making the surrounding environment both acidic (around the anode) and alkaline (around the cathode).

Hydrogen ions created on the anode dissolve in water and then react with $\mathrm{CaCO}_{3}$, which neutralizes them:

$$
\mathrm{H}^{+}+\mathrm{CaCO}_{3}=\mathrm{Ca}^{2+}+\mathrm{HCO}_{3}^{-}
$$

After this, the $\mathrm{HCO}^{-}$ions are consumed by the precipitation of $\mathrm{CaCO}_{3}$ directly on the cathode surface:

$$
\mathrm{Ca}^{2+}+\mathrm{HCO}_{3}{ }^{-}+\mathrm{OH}^{-}=\mathrm{CaCO}_{3}+\mathrm{H}_{2} \mathrm{O}
$$

The lower the $\mathrm{pH}$, the more soluble the calcium carbonate. This is because the changes in $\mathrm{pH}$ are directly correlated to changes in carbonate ion concentrations in water. Bicarbonate and carbonate are both forms of the same ion, but at a lower $\mathrm{pH}$, the bicarbonate form $\left(\mathrm{HCO}_{3}{ }^{-}\right)$predominates, whereas at a higher $\mathrm{pH}$, the carbonate form $\left(\mathrm{CO}_{3}{ }^{2-}\right)$ does.

At high $\mathrm{pH}$ levels $(9+)$, brucite $\left(\mathrm{Mg}(\mathrm{OH})_{2}\right)$ will be favored to precipitate instead of aragonite. At a normal $\mathrm{pH}(7)$, the seawater will cause the brucite to dissolve and release hydroxyl ions. The hydroxyl ions will therefore raise the $\mathrm{pH}$ and convert bicarbonate to carbonate ion, which reacts with calcium ions. In this act, the material grows and brucite ages, and it is replaced by aragonite. Brucite is similar in appearance to aragonite, but it is structurally weak and easily mechanically broken off.

The process of electrolysis also creates oxygen gas on the anode, which attracts sea life [31]. The size and shape of the submerged conductive structure determines the shape of the material structure created. The rate of the growth could reach up to $2 \mathrm{~cm}$ per year [27], depending on different environmental conditions, including temperature and salinity, but also imposed potential. As long as the power is supplied to the structure, the coating keeps growing under the constant accumulation of calcium carbonate. It possesses the ability to regenerate if a piece is broken off or manually removed, which makes it a great self-regenerating material for structures that require a lot of resources to maintain, compared to other marine construction materials.

The self-regenerating property is the result of the electrical field distribution. At first, the electrical gradient between the anode and the cathode cause the growth of the mineral all over the cathode surface, beginning close to the connection points and on sharp extremities. The metal used for the cathode has the same voltage potential throughout its whole length. If, at any point, a piece of the mineral is removed, it creates an increased current density and mass transfer flow through water at that point, causing increased precipitation until the new material is as resistive as the rest of the coating. The hydrogen gas production is also increased, and that is normally associated with a more porous structure of the precipitated material [32].

\section{Materials and Methods}

\subsection{Study Area}

Field experiments were carried out in the waters of Hanstholm port (Denmark). This is the first time that that the technology is used in a cold-water marine system. Seawater was analyzed by Inductively Coupled Plasma analysis (ICP) before the beginning of the experiments (Table 2).

Ideally, the tests would last one year, but North Jutland was hit by record wind storms between 2018 and 2019, and the facility was severely damaged only 40 days after the set up was in place; there was a power short-circuit a few hours after we installed. 
Table 2. Inductively Coupled Plasma (ICP) water analysis results.

\begin{tabular}{cc}
\hline ICP Elements & $\mathbf{m g} / \mathbf{L}$ \\
\hline $\mathrm{Ca}$ & 481.4 \\
\hline $\mathrm{Mg}$ & 1269 \\
\hline $\mathrm{Na}$ & 7252 \\
\hline $\mathrm{K}$ & 757.9 \\
\hline $\mathrm{Sr}$ & 6.2 \\
\hline
\end{tabular}

\subsection{Hanstholm Experiment and Monitoring}

The experimental system in Hanstholm harbor consisted of a self-contained hard plastic box adequately perforated to allow water circulation, containing the 6 sets of cathodes ( 2 per shape, all pre-weighted), anode, data logger for conductivity and water temperature, and secured connections. The cathodes were placed around the anode at an average distance of circa $16 \mathrm{~cm}$ from the centroids. All electrical connections were isolated and the anode connection was waterproof (silicon).

The experimental system was located at ca. $20 \mathrm{~cm}$ above the sea bottom (at $5 \mathrm{~m}$ below surface) with a rope to minimize the deposition of fine particles over the electrodes, as much as possible which can negatively influence calcium carbonate accretion and yields [38,39].

The cathodes were pieces of circa $10 \times 10 \mathrm{~cm}$ of metal grid, untreated steel, and net shaped by hand into cylinders and blocks. The Dimensionally Stable Anode (DSA) was $9.5 \times 4.6 \times 0.2 \mathrm{~cm}$.

Once in the water, a voltage of 5-5.5 $\mathrm{V}$ was applied for few seconds until bubbling on the anode was observed, and then the voltage was set to $2.5 \mathrm{~V}$ with $0.3 \mathrm{~A}$. The power was sourced from the electrical grid from a pole $100 \mathrm{~m}$ away from the installation. Power consumption was monitored. The experiments were run at a constant $2.5 \mathrm{~V}$. The current was initially $0.3 \mathrm{~A}$, and then shifted to $0.2 \mathrm{~A}$ until the end of the tests.

During the inspection of the site, there was a bit of wind and some ripples/small waves on the surface of the sea. Everything worked properly, and a layer of solid white material covered the cathodes. The conductivity was measured directly with a probe during installation and at each inspection.

Once recovered, the cathodes were transported to the laboratory and washed with deionized water before drying. Dried samples were then treated in a muffle furnace at $550{ }^{\circ} \mathrm{C}$ for $4 \mathrm{~h}$ to remove any traces of organic matter. The total amount of deposited material was obtained by differences between the weight of the cathode at the end and before the beginning of the experiment. The composition of material, after grinding to fine powder, was determined by X-ray diffraction (XRD) analysis.

\subsection{Laboratory Experiment}

The laboratory experimental system consisted of a plastic tank $(20 \times 20 \times 31 \mathrm{~cm})$, containing approximately $9 \mathrm{~L}$ of water, with stirring, water inlet and outlet, and a pump for water exchange (Figure 3). The water inlet was placed $4 \mathrm{~cm}$ from the bottom of the tank, while the outlet was placed $15 \mathrm{~cm}$ from the bottom. The tank was either placed in room temperature or in a fridge, depending on the temperature of the experiment.

The power supply used was a Powerbox LBX 30-200 (0-30 V, 0-200 A). The electrodes were connected to the power supply with bolts through a metal ring in the end of the electrode cable. Up to four experiments were connected to the power supply. The power supply has permission to execute constant current experiments because it was believed to be convenient to have a constant current density to the cathode for the production of electrodeposited mineral material. 


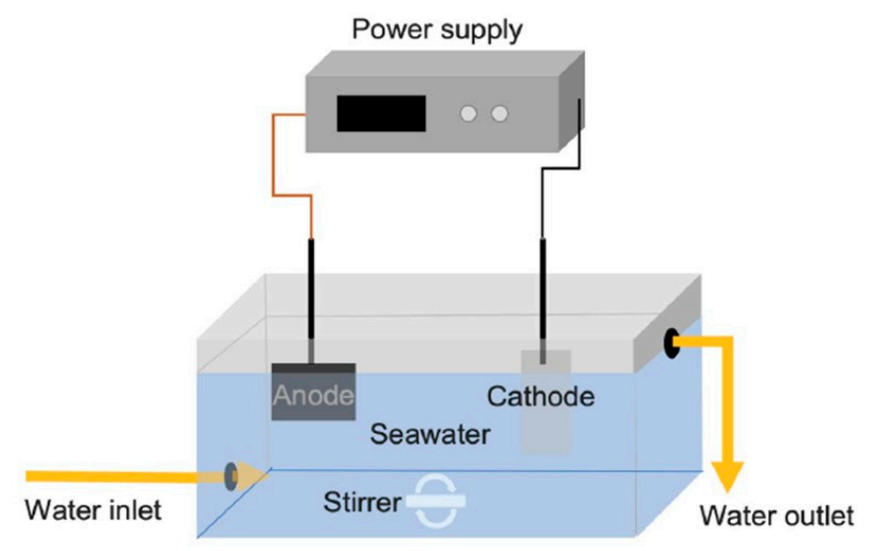

Figure 3. Overview of laboratory experimental setup.

Preliminary experiments showed that a constant applied current of 0.25 A made it possible to produce aragonite, so this was chosen as the lower level of applied current. After the first series of samples at $0.25 \mathrm{~A}$, it was observed that the material had a greater amount of brucite than aragonite. It was therefore decided to reduce the lower level of the experiments to $0.22 \mathrm{~A}$. The application of current lower than this level did not cause mineral deposits. The maximum applied current level, also known from preliminary experiments, was $0.31 \mathrm{~A}$.

For the experiments, synthetic seawater prepared with different compositions was used. One was prepared according to the standard solution of marine water by the American Society of Testing and Materials (hereinafter referred to as ASTM) (ASTM D1114-98) [40], while the other had the local concentration of $\mathrm{Mg}^{2+}$ and $\mathrm{Ca}^{2+}$ (hereinafter referred to as ESBJ).

The synthetic seawater was prepared in batches of $10 \mathrm{~L}$. NaCl, $\mathrm{Na}_{2} \mathrm{SO}_{4}, \mathrm{KCl}$, and $\mathrm{NaHCO}_{3}$ were dissolved in $1 \mathrm{~L}$ of deionized water, $\mathrm{MgCl}_{2}$ was dissolved in 2 or $3 \mathrm{~L}$ of water for ASTM and ESBJ, respectively, and $\mathrm{CaCl}_{2}$ was dissolved in $1 \mathrm{~L}$ deionized water. This procedure was necessary to prevent the salt from precipitating during preparation. The dissolved salts were then mixed together in deionized water for a total of $10 \mathrm{~L}$, followed by a pH adjustment to 8.2 by addition of $0.1 \mathrm{M} \mathrm{NaOH}$.

The experiment was carried out at two temperature levels, $7^{\circ} \mathrm{C}$ (low level) and room temperature, $22{ }^{\circ} \mathrm{C}$ (high level). The low level is that of the typical temperature of local sea water, while the high temperature falls within the range in which the electrodeposition was described in the literature.

For the electrolysis reaction, two inert anode materials were tested, the dimensionally stable anode (DSA), optimized for the oxygen reaction and consisting of a titanium plate covered with mixed metal oxides, and a platinum-coated titanium anode (Pt-Ti). The connection between the anode and the cable was modeled in silicon, as contact with water caused corrosion by interrupting the connection.

The cathodes are $2 \mathrm{~mm}$ carbon steel plates cut into $6 \times 10 \mathrm{~mm}$ pieces. Silicone was added to the top $2 \mathrm{~cm}$ of the cathode to prevent this part from reacting with synthetic seawater. Before starting the experiment, the cathodes were subjected to pretreatment, and constant voltage was applied for $24 \mathrm{~h}$ to create an initial layer of material. This initial layer was necessary to increase the resistance of the system so that it could add the required voltage to a given current applied. The pretreatment procedure involved the preparation of approximately $3 \mathrm{~L}$ of ASTM seawater solution for each cathode that had to be pretreated. There was no water flow during these $24 \mathrm{~h}$. During pretreatment, DSA anodes were used and a constant voltage of $2.2 \mathrm{~V}$ was applied.

The experiments were divided into "groups" of four that were connected to the same power supply and run simultaneously at the same applied current. Two experiments were running at the low temperature, while the other two used the setup at room temperature. The water composition and the electrode materials were randomly distributed between the experiments. Each experiment lasted for 14 days, for a total of 21 experiments. Some of the experiments had to be repeated, as the applied current was too high to produce aragonite $(0.25 \mathrm{~A})$. These experiments were repeated (marked $\mathrm{N})$ at $0.22 \mathrm{~A}$. Material produced by applying $0.25 \mathrm{~A}$ was only analyzed once, while the other samples 
were analyzed three times by XRD. After 14 days of experiments, the cathode was removed from the tank and washed in deionized water to avoid the deposition of crystals from the synthetic seawater (e.g., $\mathrm{NaCl}$ ) over the electrodeposited material during drying. The mass of the deposited material was obtained by differences between the weight of the cathode at the end and before the beginning of the experiment. The material, once removed from the cathodes, was ground using a pestle to obtain a fine powder for XRD analysis.

\section{Results and Discussion}

\subsection{Field Experiments in the Hanstholm Harbor}

Seawater temperature and conductivity values, recorded every $30 \mathrm{~min}$ (for a total of about 13,770 data values for each of the parameters) during the installation, are reported in Figures 4 and 5, respectively. The temperature ranged from 2.4 to $20.0^{\circ} \mathrm{C}$. The conductivity varied from 6700 to $37,530 \mu \mathrm{S} / \mathrm{cm}$. Such high variability of thermo-haline conditions reflects the typical temporal variations occurring in the study sites, including changes induced by meteorological forcing (cold winds, precipitation/evaporation processes), as the harbor a small and semi-enclosed basin.

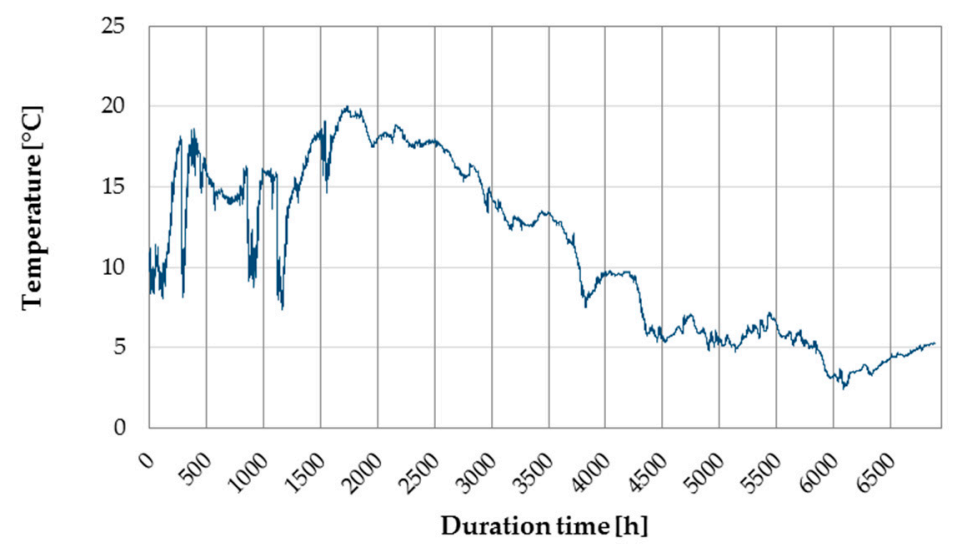

Figure 4. Temporal changes of seawater temperature from 24 May 2018 to 7 March 2019.

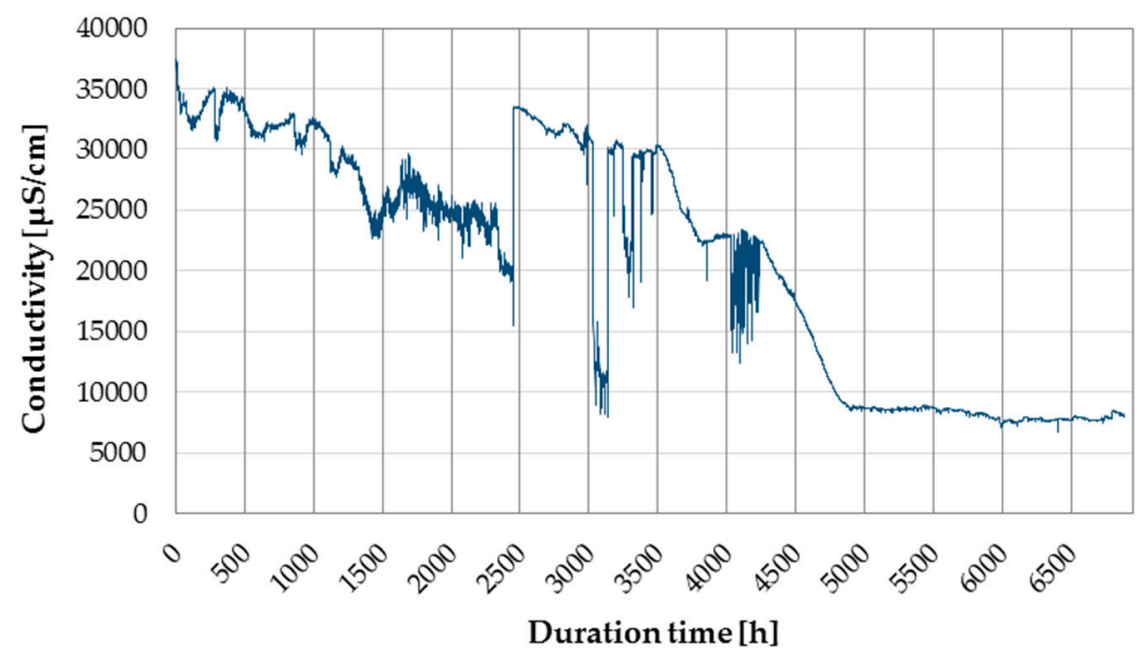

Figure 5. Temporal changes of seawater conductivity from 24 May 2018 to 7 March 2019.

The XRD analysis of the mineral sample (Table 3) showed that the material became stronger over time, with an increase of the quantitative relevance of aragonite from $65.9 \%$ to $75.8 \%$. This composition is rather similar to the one found for a sample kindly provided to us from the installation in the Hin 
Fai location of Koh Tao island in Thailand. This features $78 \%$ aragonite and $22 \%$ brucite. By this comparison, we can say that equally hard material can be precipitated in cold waters too.

Table 3. Comparison of mineral composition analyses after two weeks and after three months.

\begin{tabular}{cc}
\hline Composition after 2 Weeks & Composition after 3 Months \\
\hline Aragonite: 65.9 & Aragonite: $75.8 \%$ \\
Brucite: $33.2 \%$ & Brucite: $23.3 \%$ \\
\hline Calcite: $0.8 \%$ & Calcite: $0.8 \%$ \\
\hline
\end{tabular}

\subsection{Weight of the Mineral Deposition}

The layer of deposited material was between 2-7 mm depending on the location, showing thicker deposition where the mashes on the cathodes intersect. Accordingly, the amount of deposited material changed on the basis of the shape and dimension of the grids of the cathodes (Tables 4-6 and Figures 6-8).

Table 4. Comparison of cathode weight before and after electrodeposition (fine grid).

\begin{tabular}{|c|c|c|c|c|}
\hline \multicolumn{5}{|c|}{ FINE GRID } \\
\hline \multicolumn{5}{|c|}{ Squared shaped, plates } \\
\hline Side $1(\mathrm{~cm})$ & Side $2(\mathrm{~cm})$ & Weight before (g) & Weight after (g) & Gain (g) \\
\hline 9.5 & 10 & 13.25 & 27.97 & 14.72 \\
\hline \multicolumn{5}{|c|}{ Squared section, columns } \\
\hline 10 & & 13.5 & 26.41 & 12.91 \\
\hline
\end{tabular}

Table 5. Comparison of cathode weight before and after electrodeposition (wide grid).

\begin{tabular}{|c|c|c|c|c|}
\hline \multicolumn{5}{|c|}{ WIDE GRID } \\
\hline \multicolumn{5}{|c|}{ Squared shaped, plates } \\
\hline Side $1(\mathrm{~cm})$ & Side $2(\mathrm{~cm})$ & Weight before (g) & Weight after $(\mathrm{g})$ & Gain (g) \\
\hline 9.5 & 10 & 9.0 & 17.3 & 8.3 \\
\hline \multicolumn{5}{|c|}{ Round section, columns } \\
\hline 9.5 & 3 & 8.5 & 20.43 & 11.93 \\
\hline
\end{tabular}

Table 6. Comparison of cathode weight before and after electrodeposition (box with small stones).

\section{BOX WITH SMALL STONES}

\begin{tabular}{cccccc}
\hline \multicolumn{5}{c}{ Squared shaped, plates } \\
\hline Side 1 $(\mathrm{cm})$ & Side 2 $(\mathrm{cm})$ & Side 3 $(\mathrm{cm})$ & Weight before $(\mathrm{g})$ & Weight after $(\mathrm{g})$ & Gain $(\mathrm{g})$ \\
\hline 5.5 & 2.5 & 3.5 & 45.25 & 59.45 & 14.2 \\
\hline
\end{tabular}




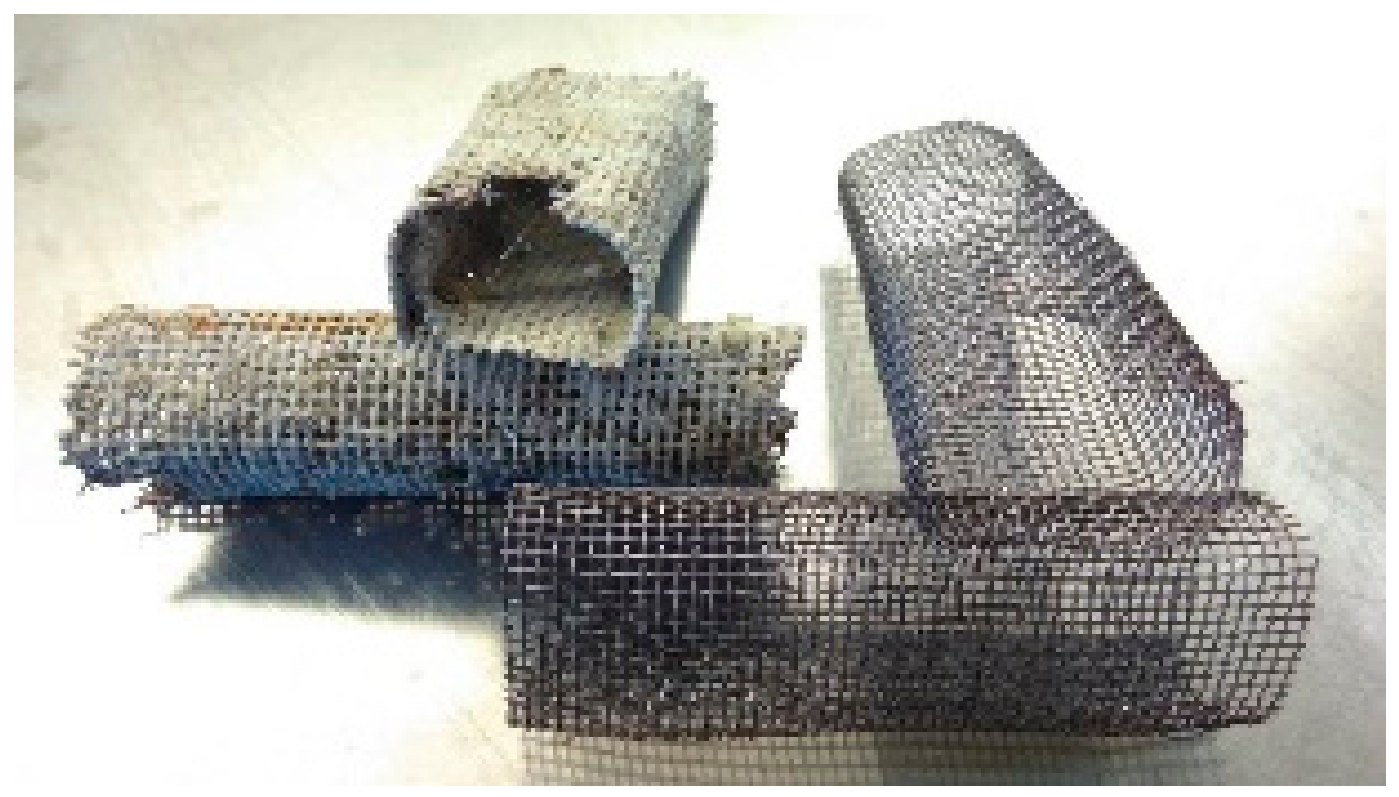

Figure 6. Fine grid cathode.

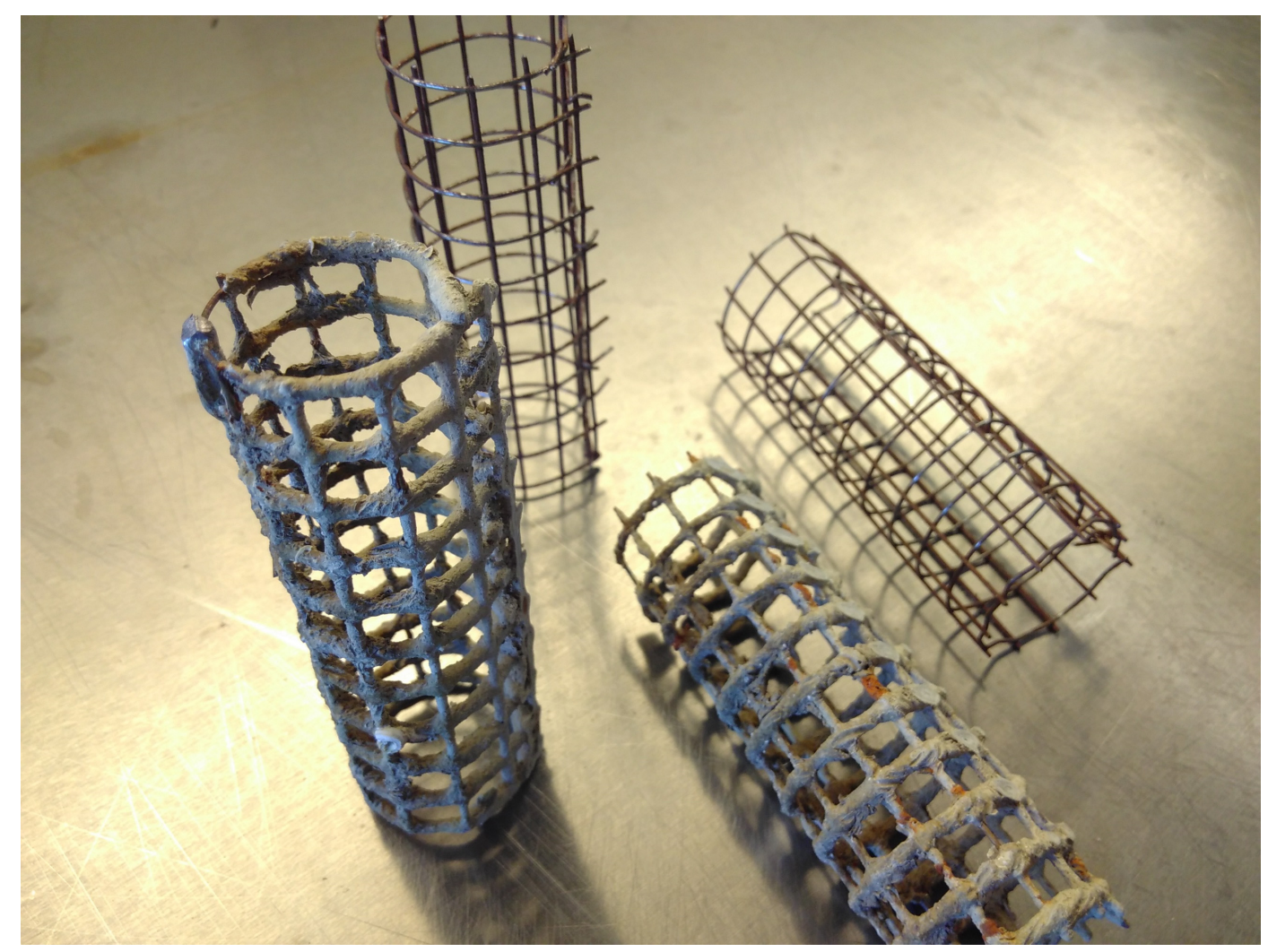

Figure 7. Wide grid cathode. 


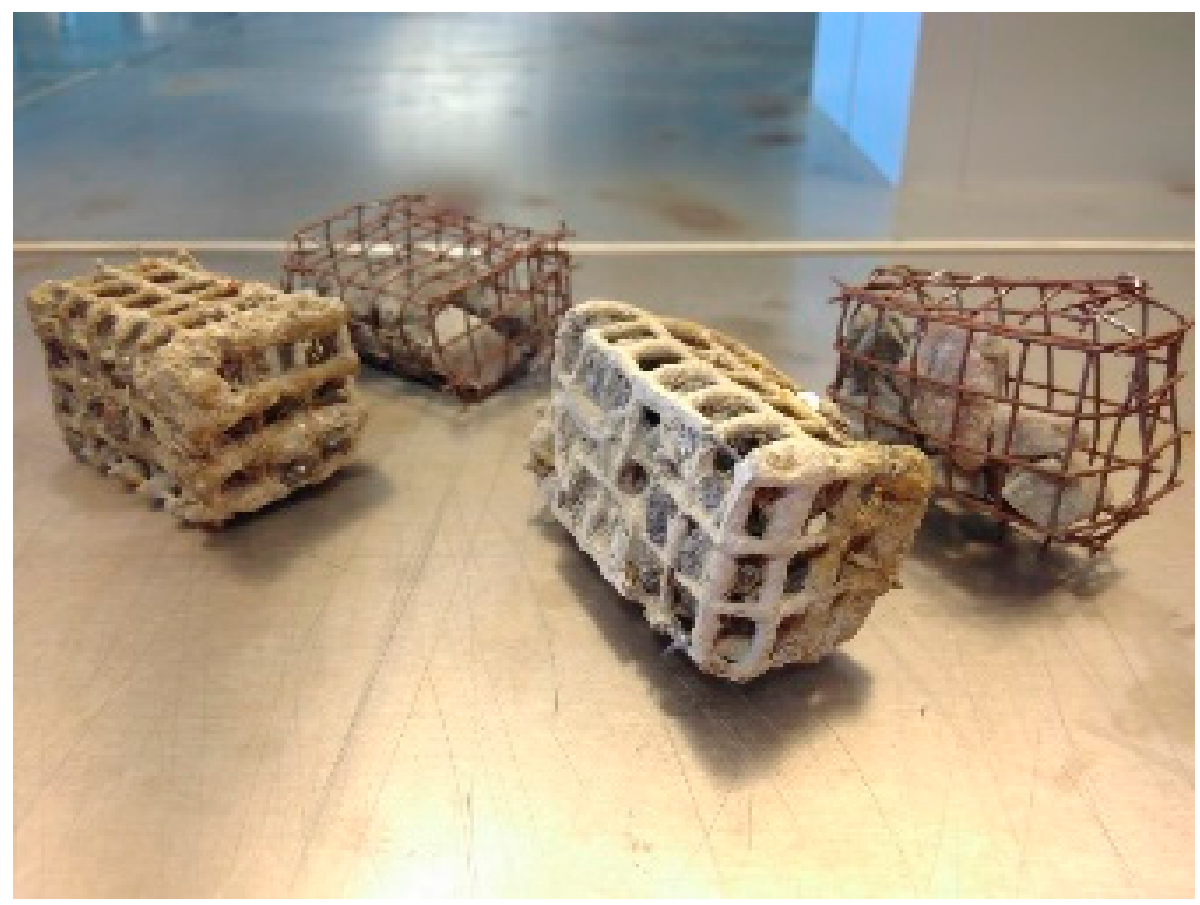

Figure 8. Box with small stones.

\subsection{Laboratory Experiments}

The mass and composition of the deposited material on the cathodes following 14 days of laboratory experiments using different conditions in terms of anode and seawater typology and current are reported in Table 7. Three different constant currents were applied in the experiments, $0.22,0.25$, and $0.31 \mathrm{~A}$, with a corresponding voltage ranging from 2.05-3.20 V. Depending on the experimental conditions, differences in the mass and composition of the deposited material were observed. Notably, the quantitative relevance of aragonite was generally much higher at the constant current of 0.22 A compared with higher current regimes (i.e., 0.25 and $0.31 \mathrm{~A}$ ).

Table 7. Mass and composition of deposited material using different experimental conditions. $\mathrm{A}=$ aragonite, $\mathrm{B}=$ brucite, $\mathrm{C}=$ calcite.

\begin{tabular}{ccccccc}
\hline Run & Anode & $\begin{array}{c}\text { Temperature } \\
\left({ }^{\circ} \mathbf{C}\right)\end{array}$ & $\begin{array}{c}\text { Constant } \\
\text { Current (A) }\end{array}$ & Water & $\begin{array}{c}\text { Material } \\
\text { Weight (g) }\end{array}$ & $\begin{array}{c}\text { Material } \\
\text { Composition }\end{array}$ \\
\hline 1 & DSA & 7 & 0.31 & ASTM & 3.9815 & $\begin{array}{c}\text { A: } 2.6 \% \text { B: } 97.3 \% \text { C: } \\
0.0 \%\end{array}$ \\
\hline 2 & DSA & 22 & 0.25 & ASTM & 2.6434 & $\begin{array}{c}\text { A: } 58.9 \% \text { B: } 40.9 \% \\
\text { C: } 0.2 \%\end{array}$ \\
\hline 3 & DSA & 22 & 0.22 & ASTM & 2.7212 & $\begin{array}{c}\text { A: } 44.1 \% \text { B: } 55.9 \% \\
\text { C: } 0.0 \%\end{array}$ \\
\hline $3 \mathrm{~N}$ & $\mathrm{Pt}-\mathrm{Ti}$ & 22 & 0.25 & ESBJ & 3.7891 & $\begin{array}{c}\text { A: } 6.8 \% \text { B: } 93.2 \% \text { C: } \\
0.0 \%\end{array}$ \\
\hline 5 & $\mathrm{Pt}-\mathrm{Ti}$ & 22 & 0.22 & ESBJ & 2.5981 & $\begin{array}{c}\text { A: } 49.1 \% \text { B: } 50.8 \% \\
\text { C: } 0.1 \%\end{array}$ \\
\hline $5 \mathrm{NY}$ & $\mathrm{Pt}-\mathrm{Ti}$ & 22 & 0.31 & ASTM & 3.4643 & $\begin{array}{c}\text { A: } 28.8 \% \text { B: } 71.1 \% \\
\text { C: } 0.0 \%\end{array}$ \\
\hline
\end{tabular}


Table 7. Cont.

\begin{tabular}{|c|c|c|c|c|c|c|}
\hline Run & Anode & $\begin{array}{l}\text { Temperature } \\
\left({ }^{\circ} \mathrm{C}\right)\end{array}$ & $\begin{array}{l}\text { Constant } \\
\text { Current (A) }\end{array}$ & Water & $\begin{array}{c}\text { Material } \\
\text { Weight (g) }\end{array}$ & $\begin{array}{c}\text { Material } \\
\text { Composition }\end{array}$ \\
\hline 7 & $\mathrm{Pt}-\mathrm{Ti}$ & 7 & 0.25 & ASTM & 2.3055 & $\begin{array}{c}\text { A: NA B: NA C: } \\
\text { NA }\end{array}$ \\
\hline $7 \mathrm{~N}$ & $\mathrm{Pt}-\mathrm{Ti}$ & 7 & 0.22 & ASTM & 2.0922 & $\begin{array}{c}\text { A: } 75.9 \% \text { B: } 24.1 \% \\
\text { C: } 0.0 \%\end{array}$ \\
\hline 8 & DSA & 7 & 0.25 & ESBJ & 2.8110 & $\begin{array}{c}\text { A: } 35.7 \% \text { B: } 64.3 \% \\
\text { C: } 0.0 \%\end{array}$ \\
\hline $8 \mathrm{~N}$ & DSA & 7 & 0.22 & ESBJ & 1.9526 & $\begin{array}{c}\text { A: } 41.5 \% \text { B: } 58.3 \% \\
\text { C: } 0.2 \%\end{array}$ \\
\hline 9 & $\mathrm{Pt}-\mathrm{Ti}$ & 7 & 0.31 & ESBJ & 3.0697 & $\begin{array}{c}\text { A: } 30.0 \% \text { B: } 69.9 \% \\
\text { C: } 0.0 \%\end{array}$ \\
\hline 10 & DSA & 7 & 0.31 & ESBJ & 2.6577 & $\begin{array}{c}\text { A: } 14.7 \% \text { B: } 85.3 \% \\
\text { C: } 0.0 \%\end{array}$ \\
\hline 11 & DSA & 22 & 0.31 & ASTM & 9.8694 & $\begin{array}{c}\text { A: } 1.5 \% \text { B: } 98.5 \% \text { C: } \\
0.0 \%\end{array}$ \\
\hline 12 & Pt-Ti & 22 & 0.31 & ESBJ & 3.4800 & $\begin{array}{c}\text { A: } 22.0 \% \text { B: } 78.0 \% \\
\text { C: } 0.0 \%\end{array}$ \\
\hline 13 & DSA & 7 & 0.22 & ASTM & 0.9534 & $\begin{array}{c}\text { A: } 80.4 \% \text { B: } 19.5 \% \\
\text { C: } 0.0 \%\end{array}$ \\
\hline 15 & DSA & 22 & 0.22 & ESBJ & 2.8917 & $\begin{array}{c}\text { A: } 21.3 \% \text { B: } 78.6 \% \\
\text { C: } 0.1 \%\end{array}$ \\
\hline 20 & DSA & 22 & 0.31 & ESBJ & 8.0931 & $\begin{array}{c}\text { A: } 2.7 \% \text { B: } 97.2 \% \text { C: } \\
0.0 \%\end{array}$ \\
\hline 22 & Pt-Ti & 7 & 0.22 & ESBJ & 1.3819 & $\begin{array}{c}\text { A: } 81.0 \% \text { B: } 19.0 \% \\
\text { C: } 0.0 \%\end{array}$ \\
\hline 26 & Pt-Ti & 22 & 0.22 & ASTM & 0.9650 & $\begin{array}{c}\text { A: } 99.4 \% \text { B: } 0.6 \% \text { C: } \\
0.0 \%\end{array}$ \\
\hline 32 & $\mathrm{Pt}-\mathrm{Ti}$ & 7 & 0.31 & ASTM & 2.9358 & $\begin{array}{c}\text { A: } 36.0 \% \text { B: } 63.9 \% \\
\text { C: } 0.0 \%\end{array}$ \\
\hline
\end{tabular}

In particular, we found an inverse relationship between the percentage of aragonite deposited on the cathode and the applied current (Figure 9). We also observed that the highest percentages of aragonite produced at 0.22 and $0.31 \mathrm{~A}$ were found in the samples where the Pt-Ti anode was used. This tendency is especially pronounced for the samples prepared at $0.31 \mathrm{~A}$. This phenomenon could be explained by the difference in activation potential for the two anodes.

Conversely, the temperature and seawater composition did not seem to have a major effect on the deposited material.

The percentage of deposited aragonite was also inversely related to the total mass of the material precipitated on the cathodes (Figure 10). These results suggest that brucite can be produced to a larger extent compared to aragonite. 


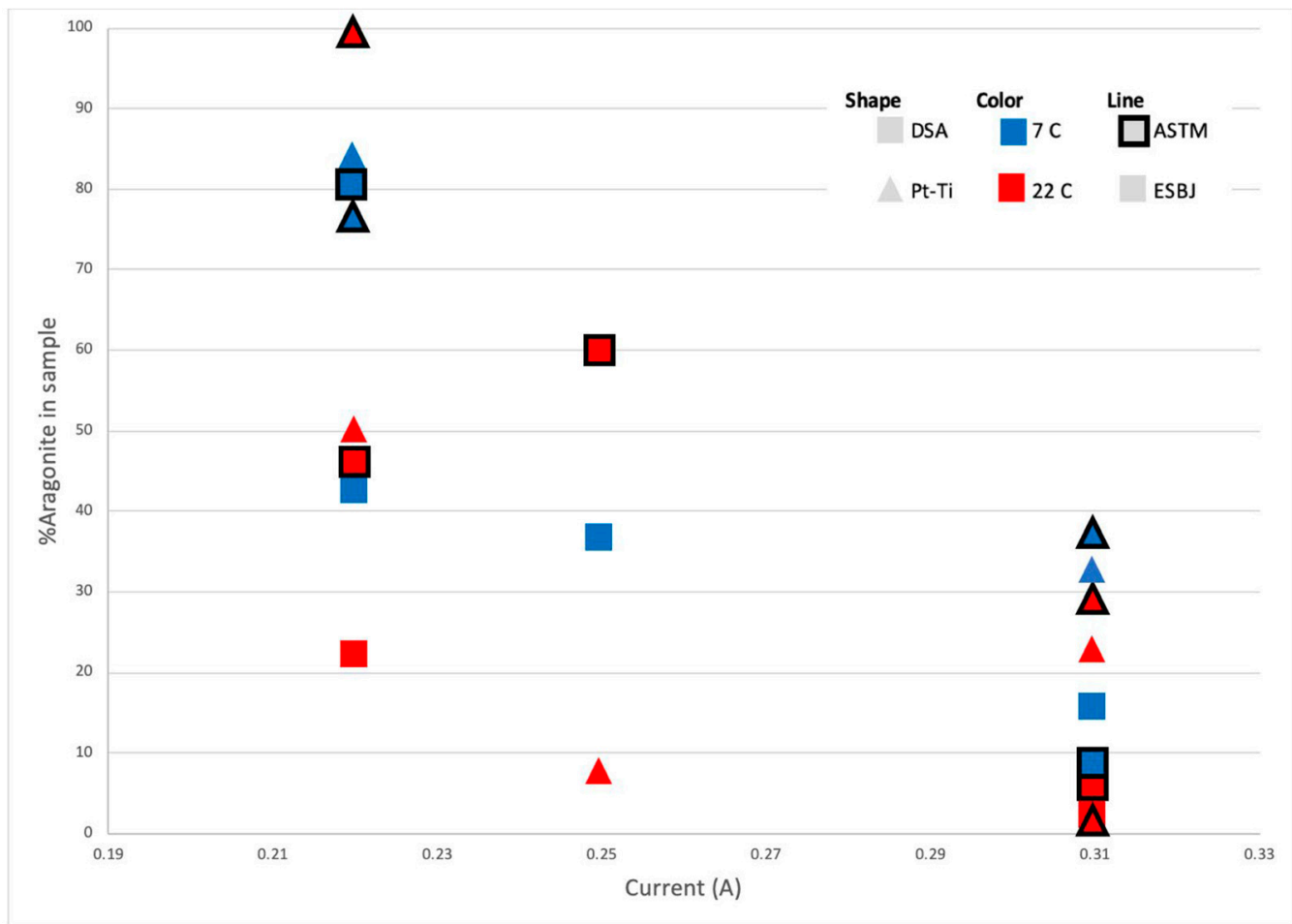

Figure 9. Applied current vs. percentage of aragonite.

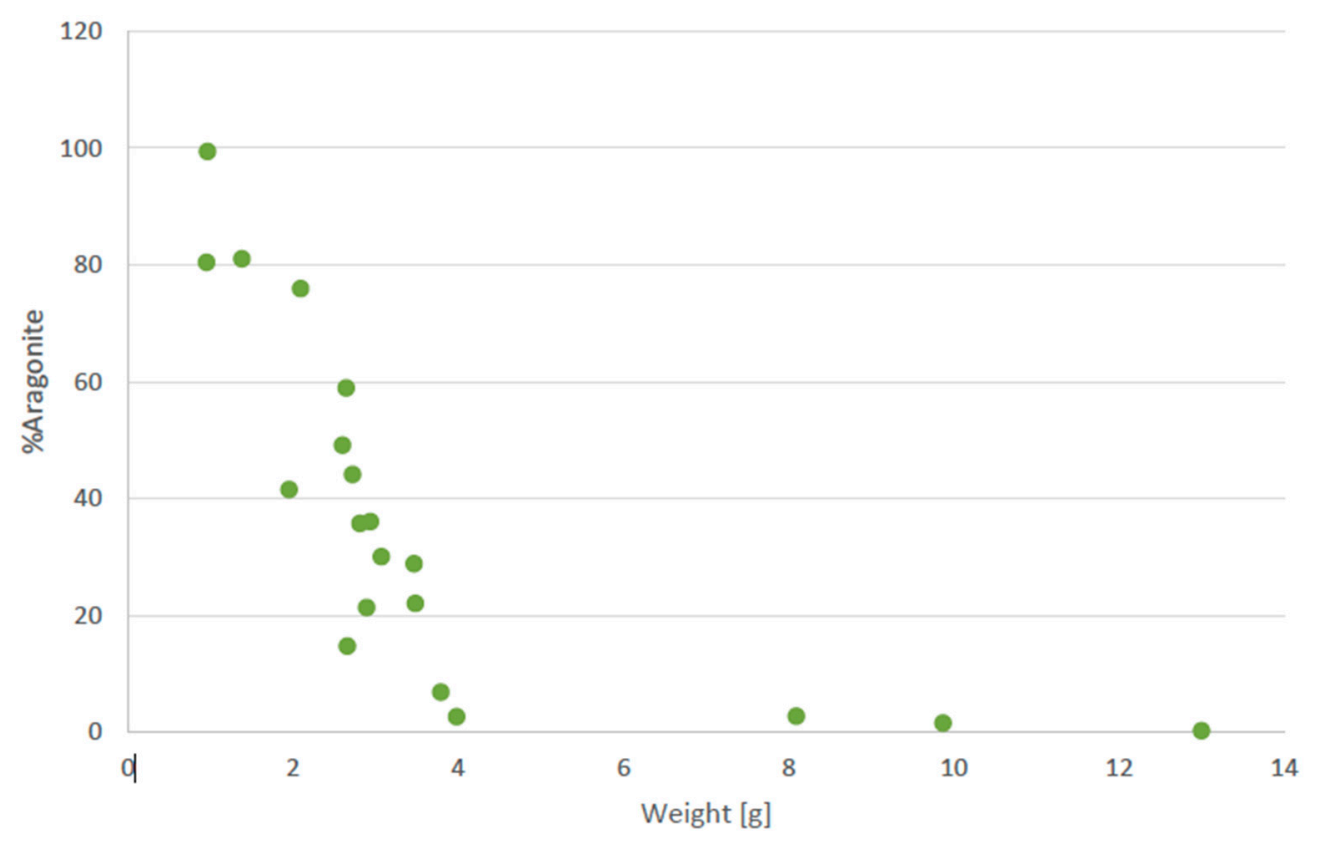

Figure 10. Weight of deposited material vs. percentage of aragonite.

\section{Conclusions}

The results from this study allowed a better understanding of the most suitable operating conditions for the application of mineral accretion technology in terms of the main parameters that influence the process (temperature, salinity, applied current), as well as the best anode and cathode materials to be used. 
In particular, from the field and laboratory experiments carried out in the present study, the following conclusions can be drawn:

(a) Temperature

A larger quantity of aragonite is deposited at a lower seawater temperature $\left(7^{\circ} \mathrm{C}\right)$ compared to that at a higher temperature regime $\left(22^{\circ} \mathrm{C}\right)$. This can be explained by differences in kinetic reactions at the two temperatures, since water electrolysis is more effective (more $\mathrm{OH}^{-}$is produced) at higher

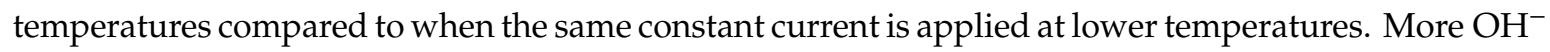
at the cathode means that more brucite precipitates.

(b) Anode material

The application of a DSA anode generally resulted in higher amount of brucite produced and more material deposited compared to the experiments where the Pt-Ti anode was used. The two electrode materials have different activation potentials, meaning the minimum potential that is required for the electrolysis reaction to start. The results indicate that the DSA anode has a higher activation potential than that of the Pt-Ti anode.

(c) Seawater composition

The use of ASTM water determines only a slightly higher deposition of aragonite compared to the use of ESBJ water. Such limited differences in ion concentrations between the two synthetic seawaters are not meaningful to appreciate differences in the composition of the deposited mineral.

(d) Applied electrical current

The applied constant electrical current seems to have a major effect on the composition of the deposited mineral at the cathode surface, since more brucite is formed at higher levels of applied current, and vice versa for aragonite. This result was expected, as the concentration of hydroxide ions $\left(\mathrm{OH}^{-}\right)$increases with increased applied current. As a result, brucite forms in a competing reaction to deposition of aragonite.

(e) Deposition rate

On the basis of the total amount of precipitated material $(0.121 \mathrm{~kg})$ and the energy consumed $(3,4 \mathrm{kWh})$, we estimated a deposition yield in Hanstholm waters of $0.04 \mathrm{~kg} / \mathrm{kWh}$, which is ca. 100 times lower than that reported in the literature [36]. Thus, further studies are needed to reduce energy consumption in relation with mineral precipitation as much as possible.

From this study, the governing conditions for the production of aragonite are low current $(0.22 \mathrm{~A})$ and low temperature $\left(7^{\circ} \mathrm{C}\right)$. In contrast to what was expected from the literature [41], these results indicate that lower temperature results in a higher percentage of aragonite compared to when the material is produced at a higher temperature. The results from the two tested anode materials indicate that the Pt-Ti anode produces material with a slightly higher percentage of aragonite compared to the DSA anode, although the latter produced promising results when used for field experiments.

Overall, the findings reported in the present study provide new elements for the application of an effective mineral accretion strategy in different marine environmental settings in addition to the tropical ones, aiming to protect steel structures from corrosion and promoting biological colonization processes [42], thus contributing to the sustainability of the natural capital.

Author Contributions: Conceptualization, L.M. and G.C.; methodology, M.E.S.; validation, L.M., M.E.S. and T.L.B., ; formal analysis, M.E.S. and T.L.B.; investigation, D.V., L.M., M.E.S. and T.L.B.; resources, L.M., D.V., M.E.S.; data curation, L.M., M.E.S., T.L.B.; writing—original draft preparation, L.M. and G.C.; writing-review and editing, G.C., D.V., P.C., C.L. and A.D.; visualization, G.C.; supervision, M.E.S., D.V., and P.C.; project administration, L.M., D.V. and P.C.; funding acquisition, L.M., M.E.S. and D.V. All authors have read and agreed to the published version of the manuscript. 
Funding: This study was carried out in the framework of the project PLaCE (PON Ricerca e Innovazione 2014-2020, project code: ARS01_00891), co-funded by the European Union and by EUDP (Energy Technology Development and Demonstration Program) https://ens.dk/en/our-responsibilities/research-development/eudp.

Acknowledgments: The authors thank ElectroCell (DK) for the manufacture and supply of anodes for the electrolysis process.

Conflicts of Interest: The authors declare no conflict of interest.

\section{References}

1. Leporini, M.; Marchetti, B.; Corvaro, F.; Polonara, F. Reconversion of offshore oil and gas platforms into renewable energy sites production: Assessment of different scenarios. Renew. Energy 2019, 135, 1121-1132. [CrossRef]

2. Truchon, S.P.; Brzuzy, L.P.; Fawcett, D.; Fonseca, M. Innovative assessments for selecting offshore-platform-decommissioning alternatives. Oil Gas. Facil. 2015, 4, 47-55. [CrossRef]

3. Techera, E.J.; Chandler, J. Offshore installations, decommissioning and artificial reefs: Do current legal frameworks best serve the marine environment? Mar. Policy 2015, 59, 53-60. [CrossRef]

4. Elenco Delle Piattaforme Marine e Strutture Assimilabili-Ministero dello sviluppo economico DGS-UNMIG-Dati al 31 dicembre 2018-Aggiornamento del 15 marzo 2019. Available online: https: //unmig.mise.gov.it/images/dati/piattaforme.pdf (accessed on 22 November 2019).

5. Fowler, A.M.; Jørgensen, A.M.; Svendsen, J.C.; Macreadie, P.I.; Jones, D.O.; Boon, A.R.; Dahlgren, T.G. Environmental benefits of leaving offshore infrastructure in the ocean. Front. Ecol. Environ. 2018, 16, 571-578. [CrossRef]

6. Martins, I.D.; Moraes, F.F.; Távora, G.; Soares, H.L.F.; Infante, C.E.; Arruda, E.F.; Lourenço, M.I. A review of the multicriteria decision analysis applied to oil and gas decommissioning problems. Ocean Coast. Manag. 2019, 184, 105000. [CrossRef]

7. Sommer, B.; Fowler, A.M.; Macreadie, P.I.; Palandro, D.A.; Aziz, A.C.; Booth, D.J. Decommissioning of offshore oil and gas structures-Environmental opportunities and challenges. Sci. Total Environ. 2019, 658, 973-981. [CrossRef]

8. Day, M.D.; Gusmitta, A. Decommissioning of offshore oil and gas installations. In Environmental Technology in the Oil Industry; Springer: Berlin/Heidelberg, Germany, 2016; pp. 257-283.

9. Macreadie, P.I.; Fowler, A.M.; Booth, D.J. Rigs-to-reefs: Will the deep sea benefit from artificial habitat? Front. Ecol. Environ. 2011, 9, 455-461. [CrossRef]

10. State Parties/Signatories: Geneva Conventions of 12 August 1949. In International Humanitarian Law; International Committee of the Red Cross: Geneva, Switzerland, 22 January 2007.

11. Despagnet, F. Cours de Droit International Public, 3rd ed.; Larose et Tenin: Paris, France, 1905.

12. International Maritime Organization. Available online: http://www.imo.org (accessed on 13 December 2019).

13. London Convention; International Maritime Organization: London, UK, 30 September 2016.

14. OSPAR Convention. Available online: https://www.ospar.org/convention (accessed on 15 January 2020).

15. Tavoso, M.A. The Barcelona Convention for the Protection of the Mediterranean Sea Against Pollution and Sustainable Development; MAP Technical Reports Series; UNEP: Nairobi, Kenya, 1997.

16. Jaron, A. Basle Convention on the Control of Transboundary Movements of Hazardous Wastes. Gewasserschutz Wasser Abwasser 1995, 152, 12-1.

17. Ehlers, P. The Baltic Sea area: Convention on the protection of the marine environment of the Baltic Sea area (Helsinki Convention) of 1974 and the revised convention of 1992. Mar. Pollut. Bull. 1994, 29, 617-621. [CrossRef]

18. Energy Mare. Available online: http://www.energymare.eu (accessed on 15 January 2020).

19. DTU Mechanical Engineering. Available online: https://www.mek.dtu.dk/english/research/feature_articles/ mermaid. (accessed on 15 January 2020).

20. Structural Design of Wave Energy Devices (SDWED) 2010-2014. Available online: https://www.civil.aau.dk/ Project+websites/sdwed/ (accessed on 15 January 2020).

21. ISMAR - Institute of Marine Sciences. Available online: http://www.ismar.cnr.it/projects/internationalprojects/copy11_of_project-001/theseus-project?set_language=en\&cl=en (accessed on 20 January 2020). 
22. MUSES-Multi Use in European Seas. Available online: https://ec.europa.eu/inea/en/horizon-2020/projects/ h2020-energy/blue-growth/muses. (accessed on 20 January 2020).

23. Azzellino, A.; Lanfredi, C.; Contestabile, P.; Ferrante, V.; Vicinanza, D. Strategic environmental assessment to evaluate WEC projects in the perspective of the environmental cost-benefit analysis. In Proceedings of the Twenty-first International Offshore and Polar Engineering Conference, Maui, HI, USA, 19-24 June 2011; International Society of Offshore and Polar Engineers: Mountain View, CA, USA, 2011.

24. Contestabile, P.; Lauro, E.D.; Galli, P.; Corselli, C.; Vicinanza, D. Offshore wind and wave energy assessment around Malè and Magoodhoo Island (Maldives). Sustainability 2017, 9, 613. [CrossRef]

25. Gazzetta Ufficiale Della Repubblica Italiana. Available online: https://www.gazzettaufficiale.it/eli/id/2019/03/ 08/19A01522/sg (accessed on 18 November 2019).

26. PlaCE. Available online: https://bluegrowth-place.eu/ (accessed on 10 January 2020).

27. Goreau, T.; Prong, P. Biorock electric reefs grow back severely eroded beaches in months. J. Mar. Sci. Eng. 2017, 5, 48. [CrossRef]

28. Strömberg, S.M.; Lundälv, T.; Goreau, T.J. Suitability of mineral accretion as a rehabilitation method for cold-water coral reefs. J. Exp. Mar. Biol. Ecol. 2010, 395, 153-161. [CrossRef]

29. Ersdal, G.; Hörnlund, E. Assessment of offshore structures for life extension. In Proceedings of the ASME 2008 27th International Conference on Offshore Mechanics and Arctic Engineering, Estoril, Portugal, 15-20 June 2008; American Society of Mechanical Engineers: New York, NY, USA, 2008; pp. 277-284.

30. Hilbertz, W.H.; Goreau, T.J. Method of Enhancing the Growth of Aquatic Organisms, and Structures Created Thereby. U.S. Patent No. 5,543,034, 6 August 1996.

31. Sabater, M.G.; Yap, H.T. Growth and survival of coral transplants with and without electrochemical deposition of CaCO3. J. Exp. Mar. Biol. Ecol. 2002, 272, 131-146. [CrossRef]

32. Goreau, T.J. Marine Electrolysis for Building Materials and Environmental Restoration. In Electrolysis; InTech Publishing: Rijeka, Croatia, 2012; pp. 273-290.

33. Calero, J.C.; Llorca, M.C.; Terradillos, P.G. Influence of different ways of chloride contamination on the efficiency of cathodic protection applied on structural reinforced concrete elements. J. Electroanal. Chem. 2017, 793, 8-17. [CrossRef]

34. Karoui, H.; Riffault, B.; Jeannin, M.; Kahoul, A.; Gil, O.; Amor, M.B.; Tlili, M.M. Electrochemical scaling of stainless steel in artificial seawater: Role of experimental conditions on $\mathrm{CaCO}_{3}$ and $\mathrm{Mg}(\mathrm{OH})_{2}$ formation. Desalination 2013, 311, 234-240. [CrossRef]

35. Chen, T.; Neville, A.; Yuan, M. Assessing the effect of $\mathrm{Mg}^{2+}$ on $\mathrm{CaCO}_{3}$ scale formation-bulk precipitation and surface deposition. J. Cryst. Growth 2005, 275, 1341-1347. [CrossRef]

36. Hilbertz, W. Electrodeposition of minerals in sea water: Experiments and applications. IEEE J. Ocean Eng. 1979, 4, 94-113. [CrossRef]

37. Schuhmacher, H.; Van Treeck, P.; Eisinger, M.; Paster, M. Transplantation of coral fragments from ship groundings on electrochemically formed reef structures. In Proceedings of the Ninth International Coral Reef Symposium, Bali, Indian, 23-27 October 2000; Volume 2, pp. 983-990.

38. Deslouis, C.; Falaras, P.; Gil, O.; Jeannin, M.; Maillot, V.; Tribollet, B. Influence of clay on calcareous deposit in natural and artificial sea water. Electrochim. Acta 2006, 51, 3173-3180. [CrossRef]

39. Morse, J.W.; Arvidson, R.S.; Lüttge, A. Calcium carbonate formation and dissolution. Chem. Rev. 2007, 107, 342-381. [CrossRef]

40. Standard ASTM D1141; American Society for Testing and Materials: Philadelphia, PA, USA, 1999 ; Volume 11.

41. van Treeck, P.; Schuhmacher, H. Artificial reefs created by electrolysis and coral transplantation: An approach ensuring the compatibility of environmental protection and diving tourism. Estuar. Coast. Shelf Sci. 1999, 49, 75-81. [CrossRef]

42. Margheritini, L.; Møldrup, P.; Jensen, R.L.; Frandsen, K.M.; Antonov, Y.I.; Kawamoto, K.; de Jonge, L.W.; Bjørgård, T.L.; Simoson, M.E.; Vaccarella, R. Coral Relief Materials: Comparative Physical-Chemical Properties of a Biorock, a High-Voltage Sea Deposit, and Coral Reef Samples. Submitt. Sci. Rep. 2020.

(C) 2020 by the authors. Licensee MDPI, Basel, Switzerland. This article is an open access article distributed under the terms and conditions of the Creative Commons Attribution (CC BY) license (http://creativecommons.org/licenses/by/4.0/). 